\title{
How 'Carmen' became a flamenco doll. Andalusian women and Spanish folklore in films featuring tourists (1905-1975)
}

\section{Maria C. Puche-Ruiz}

To cite this article: Maria C. Puche-Ruiz (2021): How 'Carmen' became a flamenco doll. Andalusian women and Spanish folklore in films featuring tourists (1905-1975), Journal of Tourism and Cultural Change, DOI: 10.1080/14766825.2021.1943418

To link to this article: https://doi.org/10.1080/14766825.2021.1943418

\section{Published online: 25 Jun 2021.}

Submit your article to this journal ๘

\section{Џ Article views: 16}

\section{Q View related articles $\longleftarrow$}

\section{View Crossmark data ¿}




\title{
How 'Carmen' became a flamenco doll. Andalusian women and Spanish folklore in films featuring tourists (1905-1975)
}

\author{
Maria C. Puche-Ruiz (D) \\ Department of Physical Geography and Regional Geographical Analysis, University of Seville, Sevilla, Spain
}

\begin{abstract}
The main aim of this paper is to reveal how the image of Andalusian women was fossilised and re-imagined for tourism during a decisive timeframe (1905-1975), to wit, how Bizet's most well-known heroine became a reified embodiment of Spanish women by turning 'Carmen' into a highly domesticated folkloric singer, a symbolic doll. To understand how this process was showcased in cinemas, a sampling of 104 films featuring tourists has been analysed using NVivo software, detecting every mention in their plots of specific categories such as those connected with Andalusian women in folkloric films (Labanyi, J. 2004. Lo andaluz en el cine del franquismo: los estereotipos como estrategia para manejar la contradicción. Sevilla: Centro de Estudios Andaluces. https://www.centrodeestudiosandaluces.es/publicaciones/lo-anda luz-en-el-cine-del-franquismo-los-estereotipos-como-estrategia-pa ra-manejar-la-contradiccion): 'Spanish Gypsies' and 'Flamenco World'.

A first approach to the sampling suggests that the interrela tionship between these categories intensified in the 1920s and 1930s, the first period in which cinema was deliberately used as political propaganda by Spanish filmmakers, the aim being to promote tradition in the lead-up to the 1929 Ibero-American Exposition in Seville. The increasing relevance of the category of 'Andalusian Women' can also be perceived during early Fra ncoism, which is key evidence for the concept of reification of the female Gypsy dancer for tourism purposes and the transforma tion of 'Carmen' into a living, standardised Spanish souvenir during the developmentalist period.
\end{abstract}

\section{ARTICLE HISTORY}

Received 23 September 2020

Accepted 10 June 2021

\section{KEYWORDS}

Myth; Carmen; tourism;

Spain; twentieth century

\section{Introduction and scope of the study}

The diffusion of the archetype of the Spanish gypsy dancer clearly did not begin with Mérimée/Bizet's 'Carmen'. When Mérimée was writing his novella (1845), he was undoubtedly aware of the popularity of this character, developed by travel writing and early tourism in Spain. After being sidelined from the European Grand Tour, this proto-touristic image of the Andalusian woman was sustained by powerful artistic imagery and the partial visions of the very few enlightened tourists who ventured to visit this passionate and indomitable country (Jardine, Twiss, Swinburne, Ponz, Laborde, etc.). These early 
tourists also continued propagating the image of Spanish gypsies through similar 'visions of racialized entertainers, child abusers, and highway vagabonds depicted in travel novels, picture postcards [...]' (Woods Peiró, 2012, p. 51). Nevertheless, the symbolic character created by Mérimée/Bizet can be seen as the most notable (and persistent; Pujante Segura, 2010) cultural manifestation of the fusion of characteristics attributed to Andalusian women and, as a consequence, to Spanish women. It should be borne in mind that 'Mérimée's Carmen, and its accentuation by Meilhac and Halévy for Bizet, demonstrates the dominant positioning of Andalusian characteristics at the expense, or complete assimilation of Spanish ones [...]' (Utrera, 1997, p. 15), constituting a 'merit to the Frenchman [Mérimée] who managed to do what the Spanish had not been able to achieve: to create a novel and to weave a plot with all these archetypes supposedly representative of Spain and Andalusia, and to give it a romantic, Spanish and eventually universal character' (Claver Esteban, 2012, p. 76). It is not surprising, therefore, that despite its inaccuracies, 'Carmen became "one of the most popular operas ever composed, canonizing the cliché of the espagnolade on a global scale"' (Woods Peiró, 2012, p. 282; quoting Colmeiro, 2003).

In the early twentieth century, this deep-rooted French fascination for all things Spanish, which was invariably identified in literature and in music with Andalusia, was transposed to the cinema, shaping a new, idealised imaginary world of moving pictures. The evolution of this cinematic espagnolade, which introduced national symbols and iconic archetypes (as Griñán Doblas, 2016; and Cruces-Roldán, 2017, have suggested), was unavoidably connected to soft power and the tourist gaze and necessarily implied subjectivity and omission (Gallardo Saborido, 2010). Palomeque Recio (2012, p. 157) cites Lou Charnon-Deustch (2002) when she states that '[...] these three elements - the foreign, the atavistic and the racial, epitomised in the gypsy community, chiefly among women - are, together with the popularity of flamenco and its different derivations [...], those that best explain how "the gypsy dancer had become an emblem of Andalusia, and Andalusia a trope of Spain"', an aspect which was also appreciated by Hamling (2010). The embodiment of this gypsy dancer in Mérimée/Bizet's 'Carmen' and its subsequent diffusion with numerous different faces and film characters, led to transnational feedback on the big screen of a symbol which has come full circle (Benet \& Sánchez-Biosca, 2013). A construct of Spain, Spanish women and folklore (Serrano, 1999), East for Westerners and West for the Orient (Lu, 2009), which took on a life of its own, with broad and simplistic brushstrokes, going far beyond the first version offered by its creators (Sentaurens, 2002).

The character of 'Carmen' (and its numerous incarnations) henceforward appeared dancing on the screen, representing a racially stereotyped otherness from Southern Europe to satisfy the yearning of audiences and filmmakers for displays of tamed exoticism. The Franco dictatorship went on to foster a sanitised representation of the female persona in cinematic españoladas: a vernacular Carmen in flamenco dress who proclaimed herself 'Catholic and decent', as a warning to French tourists planning to travel in Spain. And tourists duly purchased sparkling, brash flamenco dolls as a standard souvenir of the original Gypsy dancer (Cisneros-Kostic, 2010), of that 'multi-coloured farce' to which Ortega y Gasset had already alluded in 1927. And the cinematic reworkings of the myth became innumerable, because of what Hernández (2008) has called 'romantic stubbornness'. See, in this respect, the exhaustive works of Perriam \& Davies, 2005; Davies \& Powrie, 2006; Powrie, Babington, Davies, \& Perriam, 2007, and at national 
level, those of Medrano García, 1990; Vera \& Meléndez, 2008 or Guarinos, 2010, to give just a few examples. Our analysis introduces a new variable into the equation, insofar as it incorporates the various reinterpretations of the myth of 'Carmen' for tourists in the films of the period 1905-1975, a period that begins with the emergence of the first Spanish and European tourist boards and that culminates with a point of inflection after the end of Francoism and its centralised tourist management in Spain.

The main aim of this paper is to demonstrate how the image of Andalusian women, connected with the 'Flamenco World' and 'Spanish Gypsies' (Labanyi, 2004), was fossilised and re-imagined for tourism during this decisive timeframe, which has been divided into four key periods ('Cinema as Document' [1905-1922]; 'Cinema becomes Propaganda' [1923-1939]; 'Years of Lead' [1940-1959], and 'Tourism. A Great Invention' [19601975]), and shows consumerism and mass tourism at their peak. After a thorough research in the catalogues of the Cinémathèque de París, the Gaumont-Pathé Archives, the catalogues of the Jérôme Seydoux-Pathé Foundation and British Pathé, as well as those of the Spanish National Film Library and the Film Library of Andalusia, a sampling of 104 films, in which tourists feature (an indispensable requisite), and are infused with a promotional purpose (Mestre, Del Rey, \& Stanishevski, 2008) of Andalusia, has been selected. Online databases have been likewise consulted, establishing search criteria (tourism, tourist, travel, Andalusia) in IMdB.com (Internet Movie Database) and Filmaffinity.

The study of the material collected has been based on content analysis of visual data (Rose, 2012), performing consistent grounded theory research (Strauss \& Corbin, 1999) through the systematic analysis of films, photographs and texts from the standpoint of visual sociology (Cipriani \& Del Re, 2012). In this regard, a decision was made to use NVivo to visualise the film sampling, to detect every mention of the three aforementioned categories and codify them, gathering the results from the four pre-established periods (see Figure 1). NVivo software pertains to the group of CAQDAS (computer-assisted qualitative data analysis software) tools, a computerised system for codifying content and constant data comparison using node matrices whose implementation in visual research may

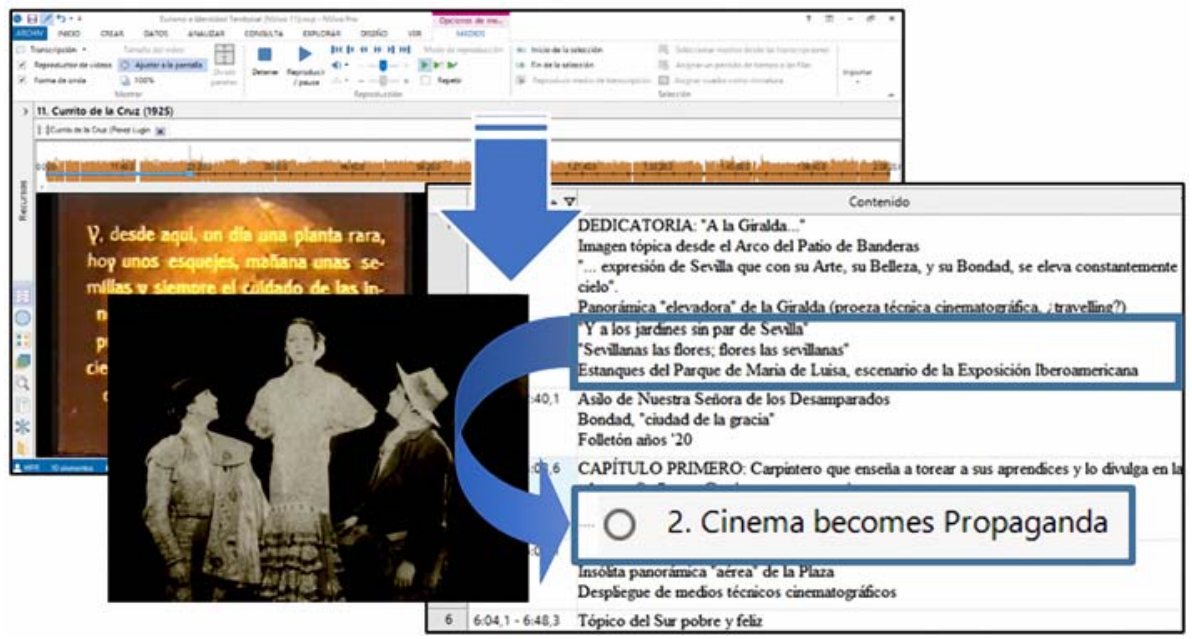

Figure 1. Methods employed (NVivo software) to visualise the sampling of films and filter references to 'Andalusian Women' within the four key periods established. Source: the author. 
be considered a novelty. This tool has assisted the author with the identification of cinematic trends and iconic characters, revealing how a transnational myth (Gravari-Barbas, 2019; Prieto Arranz, 2006; Shandley, Jamal, \& Tanase, 2006), such as Bizet's most wellknown heroine, 'Carmen', was turned into a highly domesticated folkloric singer, a symbolic, beautiful doll.

\section{Results: the role of women in films featuring tourists (1905-1975)}

In this section, three female roles in iconic films from the first three periods of our study will be analysed. These have been chosen because they are the most typical, both for the number of references they produce within the overlap of the categories 'Andalusian Women', 'Spanish Gypsies' and 'Flamenco World' (established with the NVivo software following Labanyi, 2004), and for the significance of the archetype represented within the development of the stereotype of 'Carmen' over the seventy years under consideration.

As can be seen in Figure 2, the results highlight the predominant link between 'Andalusian Women' and the 'Flamenco World' (in light blue), as opposed to their association with the gypsy group (dark blue), with the latter totalling 75 total references as opposed to 116 for the former. The interrelationship between these categories intensified during the second period ( $106.67 \%$ and $122.67 \%$, respectively), the first period in which cinema was deliberately used as political propaganda by Spanish filmmakers to promote tradition. The increasing relevance of the category of 'Andalusian Women' can also be perceived during early Francoism, key evidence for the concept of reification of the female Gypsy dancer for tourism purposes and the transformation of Carmen into a living Spanish souvenir. Nevertheless, during the period 'A Great Invention' (19601975), references to 'Andalusian Women' associated with the aforementioned categories decreased dramatically ( $48 \%$ and $282^{\prime} 67 \%$ in comparison with the previous period), and Andalusian characters almost completely vanish from the plots of films featuring tourists.

\section{$\%$ of references concerning 'Andalusian Women' linked to Spanish Gypsies and the Flamenco World in films (1905-1975)}

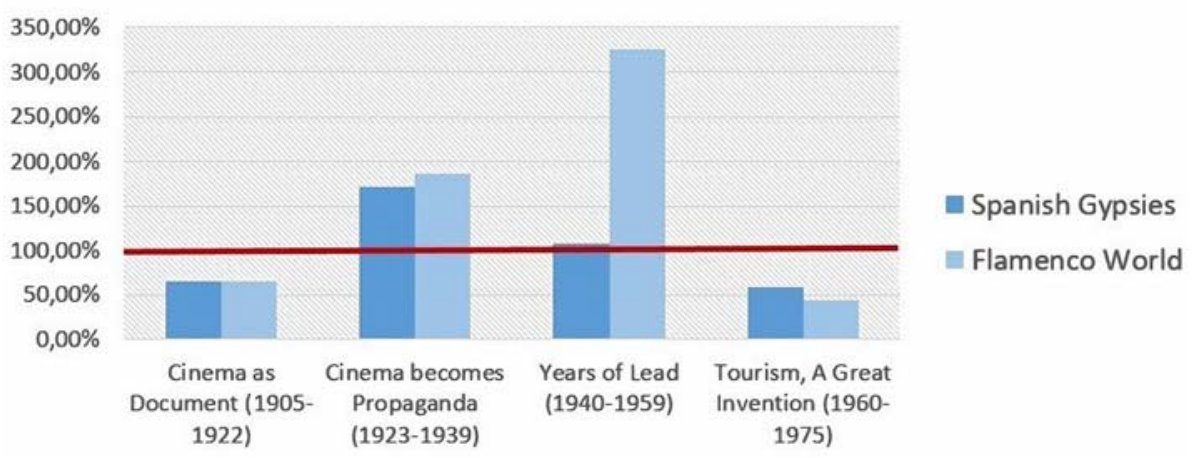

Figure 2. Interrelationship between 'Andalusian Women' and 'Spanish Gypsies' (dark blue), and 'Andalusian Women' and 'Flamenco world' (light blue) during the period of study (1905-1975). Source: the author. 
For this reason no single iconic figure of the gypsy dancer has been selected for the last period (1960-1975), which coincides with the heyday of tourism in Andalusia, since, as mentioned, at that time there was a decline in the trend. This marked decrease, along with its more balanced representation, is due to its inclusion in films as a more anecdotal theme. In this way, 'Spanish Gypsies' appear linked to 'Flamenco World' in an amalgam of films in which an essential characteristic is the anonymity of their folkloric performers and a lack of clear, recognisable female protagonists.

\subsection{Cinema as document (1905-1922): Carmen and the French melodrama. 'Sibilla' in 'El Dorado' (1921)}

The film 'El Dorado' (Marcel L'Herbier, 1921) includes up to 17 references to the key concepts analysed ('Spanish Gypsies' and 'Flamenco World'). When these are studied in relation to the stereotype of 'Andalusian Women' in tourism, it shows an unusual symmetry between both, in keeping with the trend observed for the first period. Thus, although the references are below the average (due to the fact that the sample is made up of only 8 films), the consensus around these two archetypes in primitive cinema is confirmed ('Cinema as Document', 1905-1922; see Figure 2).

This film, contrary to the theory of Regenerationism and the tourism policies of the time, perpetuates manners and customs linked to the image that Spain had promulgated through the nineteenth century Universal Exhibitions. To this end its director (Marcel L'Herbier) is more interested in showing the contrast between Spanish 'tradition' and European 'modernity' than in showing the modern image that the monarchy of Alfonso XIII intended to promote.

Its female protagonist, the young gypsy 'Sibilla' (Eve Francis), is a contradictory character precisely because of her situation between two opposing forces. This is why she demonstrates both the characteristics of the Spanish femme fatale (superstitious, proud and vengeful, according to Raymond Payelle's novelisation, 1921; see Figure 3), and the elements of film melodrama of the time: a single mother of a sick child and easy prey for rogues, which highlights, perhaps for the first time on the cinema screen, the social inequality of the descendants of 'Carmen' at the beginning of the twentieth century.

Her portrayal (Ionita, 2013; Luque Teruel, 2004), like that of the character of 'Carmen' in the opera, captures the attention of the spectator as she is forced to dance before a heterogeneous audience made up of 'elegant tourists, rough, happy workers [...], couples, girls in rags' (Payelle, 1921, p. 8), dressed in an iconic costume that makes her stand out from the rest. At the end of the tango andalou, composed by Marius-François Gaillard, 'Sibilla' throws the carnation she has worn in her bodice during the dance to the public whipping up collective hysteria in the room. Later she will do the same with '[...] a gypsy dance [...] that seems to come, mysterious and wild, from the depths of the complex past of ancient Spain. Or from even further back in time and space. It comes from the East [...]' (1921, pp. 30-31) and from the tradition that associates the gypsy dancer with the 'orientalist' trend.

The duality between the conventions of the espagnolade and French melodrama, lead its author to juxtapose the French art nouveau aesthetic with the deeply-rooted literary images of Andalusian poverty. In this sense, he equates the cruelty of the life of this 


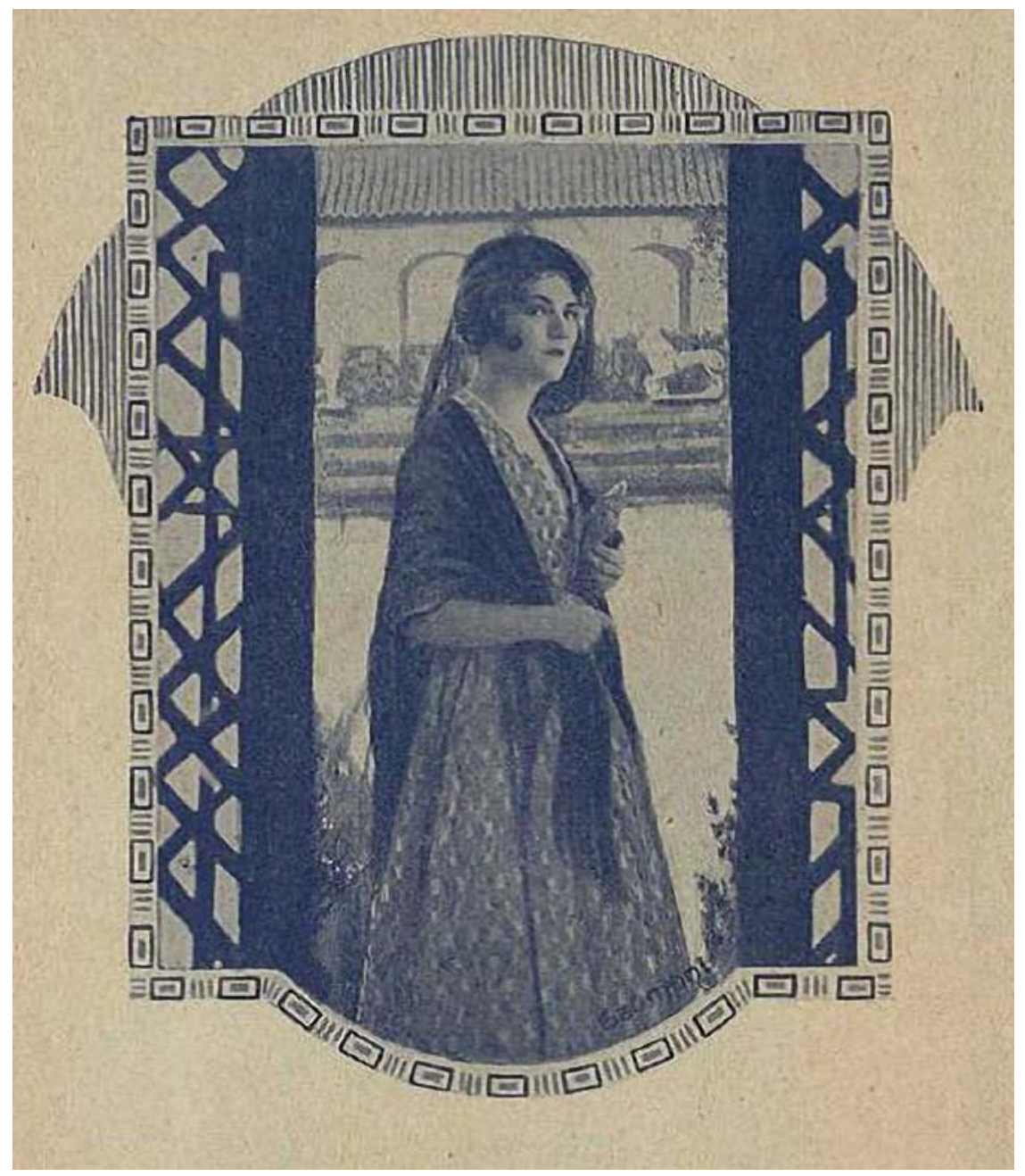

Figure 3. 'Sibilla' as a Spanish femme fatale in 'El Dorado'. Source: Cinémathèque Française.

new 'Carmen' in the Albaicín with the tradition of the Hispano-Muslim Alhambra which tourists visit, seeking: 'The old Spanish city and the enchanted palace of the Moorish kings which seem [...] to appear, both evocative of barbarism, one in its persistent poverty, the other in its marvellous remains' (Payelle, 1921, p. 7).

This contrast between 'tradition' and 'modernity' will also be highlighted in the juxtaposition of the myth of 'Carmen' and tourism, or in other words, in the confrontation between the stereotypical image of the gypsy dancer of the French espagnolade and the civilised world that tourists bring to Spain. Tourist activity thus acts both as a link between the two worlds (gypsies and non-gypsies, visitors and locals) and as an escape route from the deprivation of Sibilla's work in cabaret, but it will also demolish the phony world of her theatrical performance as she comes face to face with reality. In this way, 'Sibilla' dressed 'in her gypsy clothes [...] gesticulates as dancers do, who snap their fingers [...], she forces herself to smile, seems rejuvenated, radiant, almost far from her painful destiny' and '[...] also serves [...] as a 
guide, because she knows all the rooms, all the walks and all the patios of the palaces and gardens, the smallest nooks and crannies of the Alhambra' (47-49; see Figure 4).

But the presence of foreigners will soon introduce the necessary tension to trigger the tragedy in the film. 'Sibilla' represents a romantic archetype that, like 'Carmen', is driven, through its contradictions, to death (see Figure 5). Because 'Hedwick', although 'not insensitive to this bright and natural beauty', dreams of a young woman 'in the image and likeness of that palace, proud in her appearance and with a perfumed heart [...], with dark hair but a white soul' (52). This opposing character will be 'Illiana', whose antecedent could be Bizet's own 'Micaëla'. Thus, if 'Sibilla' embodies the forlorn Alhambra which is sold to tourists, 'Illiana' is the authentic Hispano-Muslim princess of Washington Irving's 'Tales'; an angelic character who will innocently unleash the protagonist's revenge and hasten her end.

And she will do so after one last dance, in which she '[...] lets herself go [...]. She dances with fire and violence, in front of impassioned men', and she has enormous success, the greatest of her career: 'She has rarely danced like this, fast, hot and smiling all along, with a full, beaming smile [...]. She performs her last movement, smiling, always smiling, but when the dance is over and Sibilla, in the midst of the glorious tumult, disappears behind the curtain, her smile is still radiant, it then shatters and becomes a trembling grimace [...]' (1921, pp. 108-109). 'Sibilla', a character from Spain's mythical past, ends up being overwhelmed by the vigorous modernity of the forces coming from abroad. Aware of not being able to compete with them, she gives her son to this traveller from civilisation, and no longer sees meaning in either the commerce of her dances or the prostitution of her outdated stereotype.

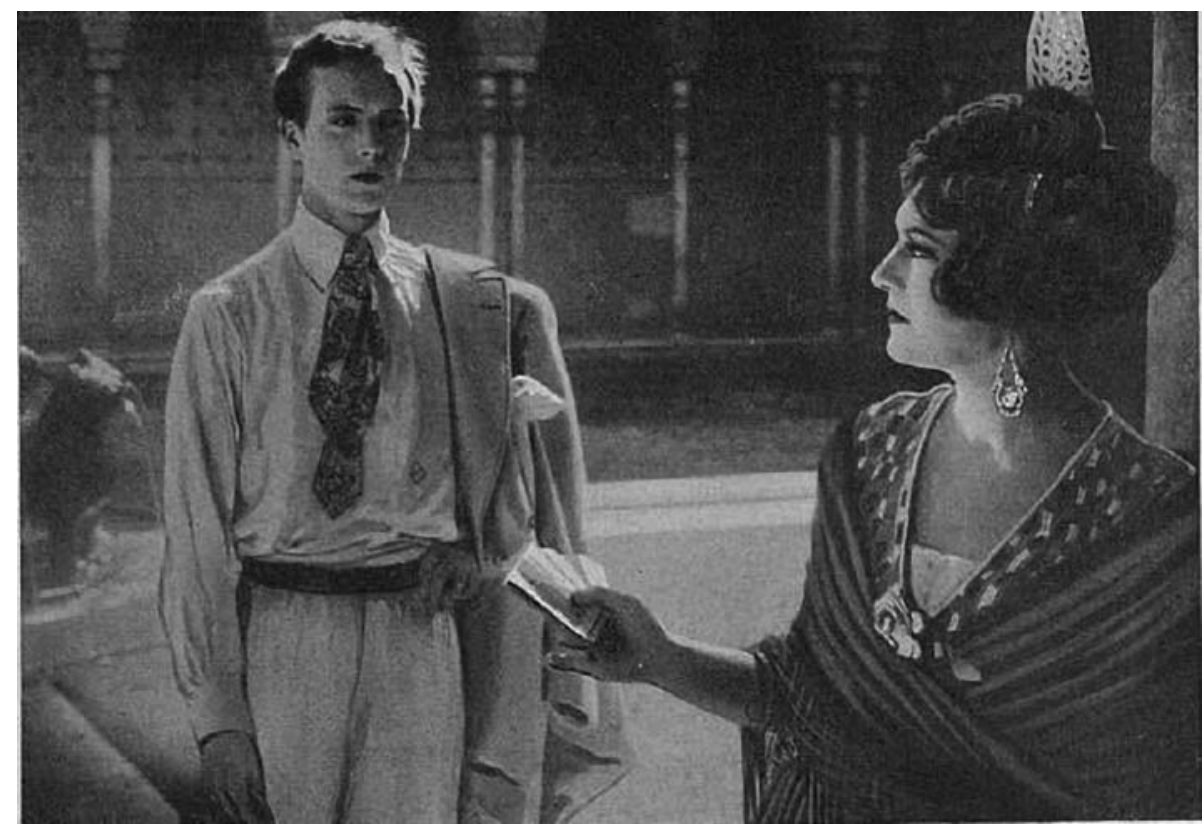

Figure 4. 'Sibilla' and the Swedish tourist 'Hedwick' in the Alhambra. Source: Cinémathèque Française. 


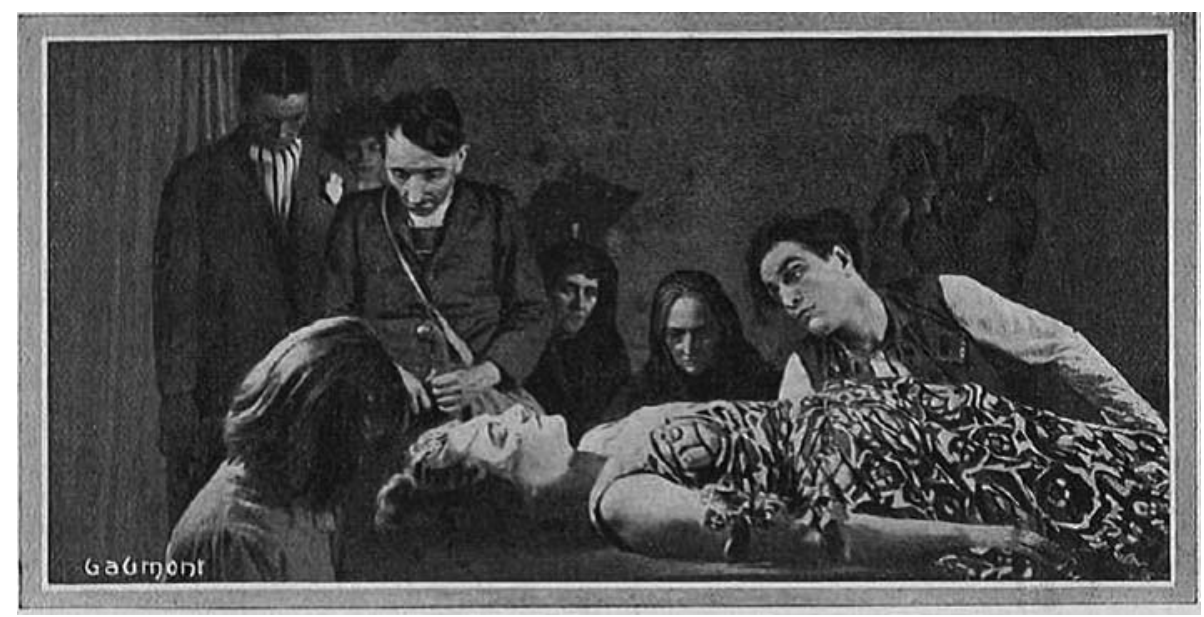

Figure 5. Fatalism of 'Carmen': the 'good death' of 'Sibilla'. Source: Cinémathèque Française.

\subsection{Cinema becomes propaganda (1923-1939): Carmen and the Españolada Nacional. 'Maria de la O' (1936)}

During the second period, the connection of 'Andalusian Women' with 'Spanish Gypsies' and the 'Flamenco World' undergoes a notable increase (of $106.67 \%$ and $122.67 \%$, respectively; see Figure 2), while still maintaining a harmonious relationship between the two. 'María de la O' (Francisco Elías Riquelme, 1936) contains 30 references to them and is an example of the most perfect fusion between an authentic españolada of national attributes (Utrera, 1997) and the Andalusian gypsy woman, associated with the growing tourist commercialisation of the flamenco world (see Figures 6 and 7). Because, as indicated by Palomeque Recio (2012, p. 157), 'the dissemination of the icon of the "Spanish woman" in this era is due [...] to the search for and creation of foundational myths as symbols that sustain the declining power of the state'.

It should be noted that during the Second Republic national archetypes were in the hands of filmmakers who, fearful of being labelled 'anti-Spanish', return to the most clichéd roots of Spanish cinema through escapist films. These films (Gubern, 1977) only aim to 'delight the public' (Lénárt, 2012, p. 107), and are more than ever associated with this 'current of folkloric-musical cinema, impregnated with Andalusian song and flamenco singing' (Sánchez Oliveira, 2003, p. 106). Technically it comes close to North American cinema (Marinero Labrador, 2012), however, it also draws attention to the paucity of ideas from the filmmakers of the period (Claver Esteban, 2012).

That is why 'María de la O' (1936), based on the play of the same name by Rafael de León and Salvador Valverde (and, in turn, on the popular song by Maestro Quiroga), 'belongs to a certain model of republican cinema in which the "españolada" branches into melodrama and folklore, "soap opera" and Andalusian genre art' (Utrera, 1998, p. 109). Not in vain, when questioned about the nature of the film, the scriptwriter José Luis Salado stated that 'María de la $\mathrm{O}^{\prime}$ ' was 'a gypsy melodrama [...]; a film of bright colour, without the "españolada", eh? to which I have tried to give the rhythm, the lightness and the agility of an American film' (Hernández-Girbal, 1936, p. 1). In order to achieve this he introduced a supposedly American character as the tourist 'Mister Moore'. 


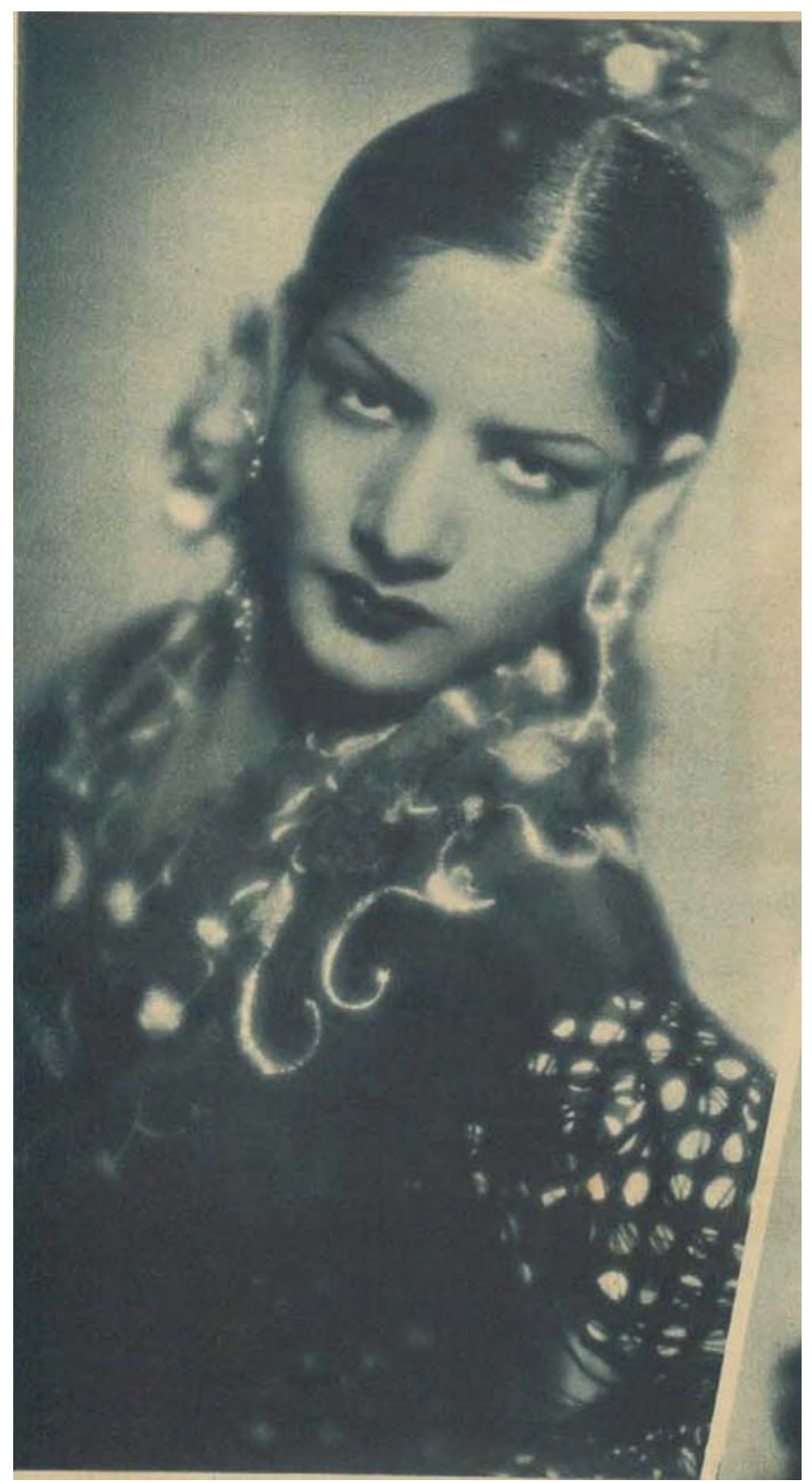

Figure 6. Young gypsy dancer Carmen Amaya as 'Maria de la O'. Source: Property of the Biblioteca Nacional de España.

This aspect of modernity is highlighted in the planning of crucial scenes, such as the murder that triggers the tragedy (Cerdán, 1997), the wake, or the solo dance of the protagonist who proclaims her innocence. These elements combine to 'construct a tormented melodrama in which certain lines of psychological realism are crossed' (Barroso \& GilDelgado, 2002, p. 83), and in which Andalusian music and folklore play a crucial role.

Along these lines, much has been theorised about the cinematographic treatment of the song 'María de la O' which seems to defame this 'Carmen', in spite of herself, as a mercenary in her love only because of obedience to her mother and her race. The melody 


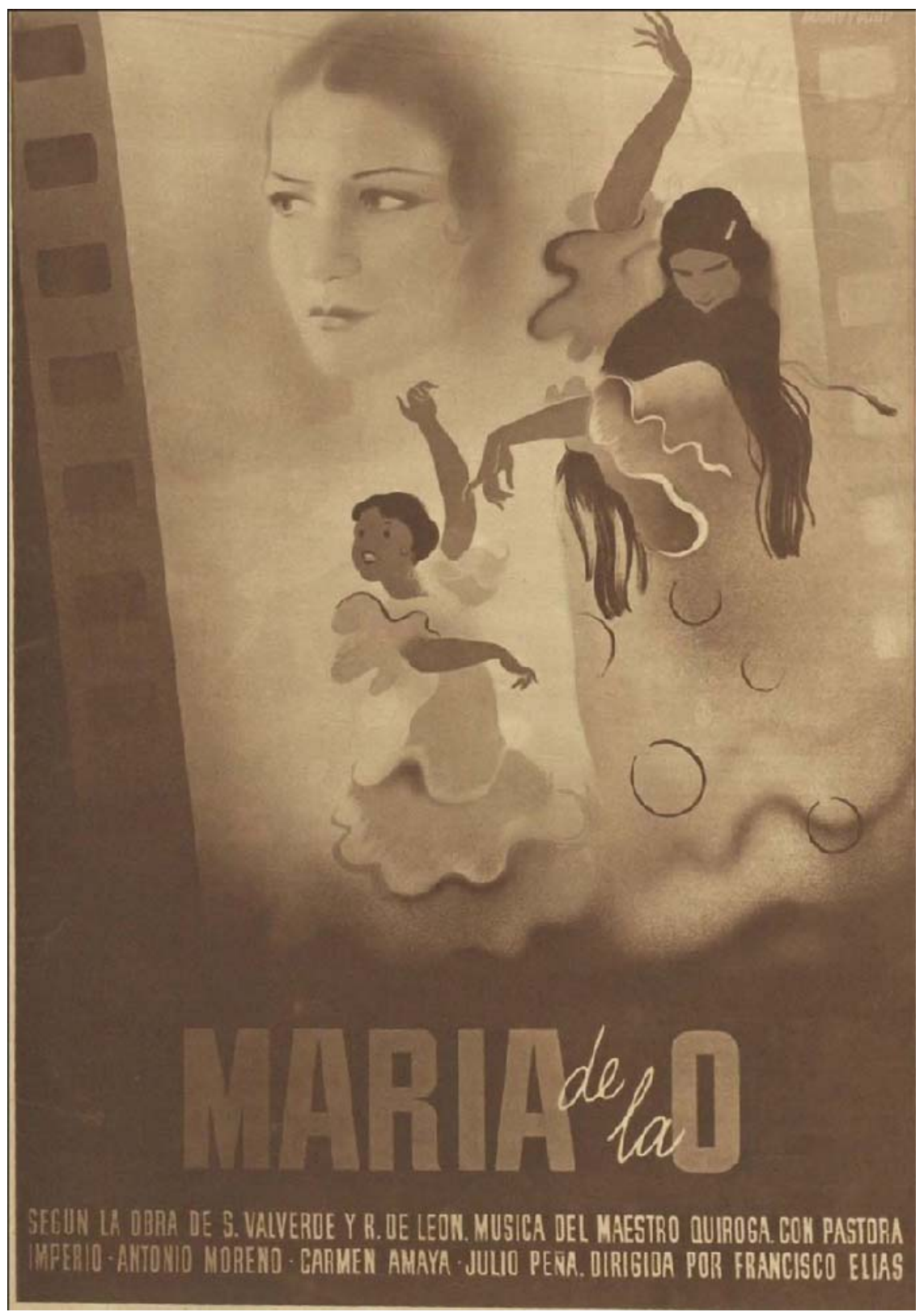

Figure 7. Poster by Briones and Oliver, winner of the first prize from Ulargui Films to promote the film 'Maria de la O'. Source: Property of the Biblioteca Nacional de España.

jumps from tavern to palace, and from there to workplaces and even to popular children's games, offering an evocative series of images of Seville (Utrera, 1997), which contrasts with the tears of the protagonist in her confinement in the sumptuous house in the Barrio de Santa Cruz.

It is significant that the perspective of the drama is not that of the gypsy herself (as occurs in Mérimée's novel), but the distorted one that arises from the pique of an 


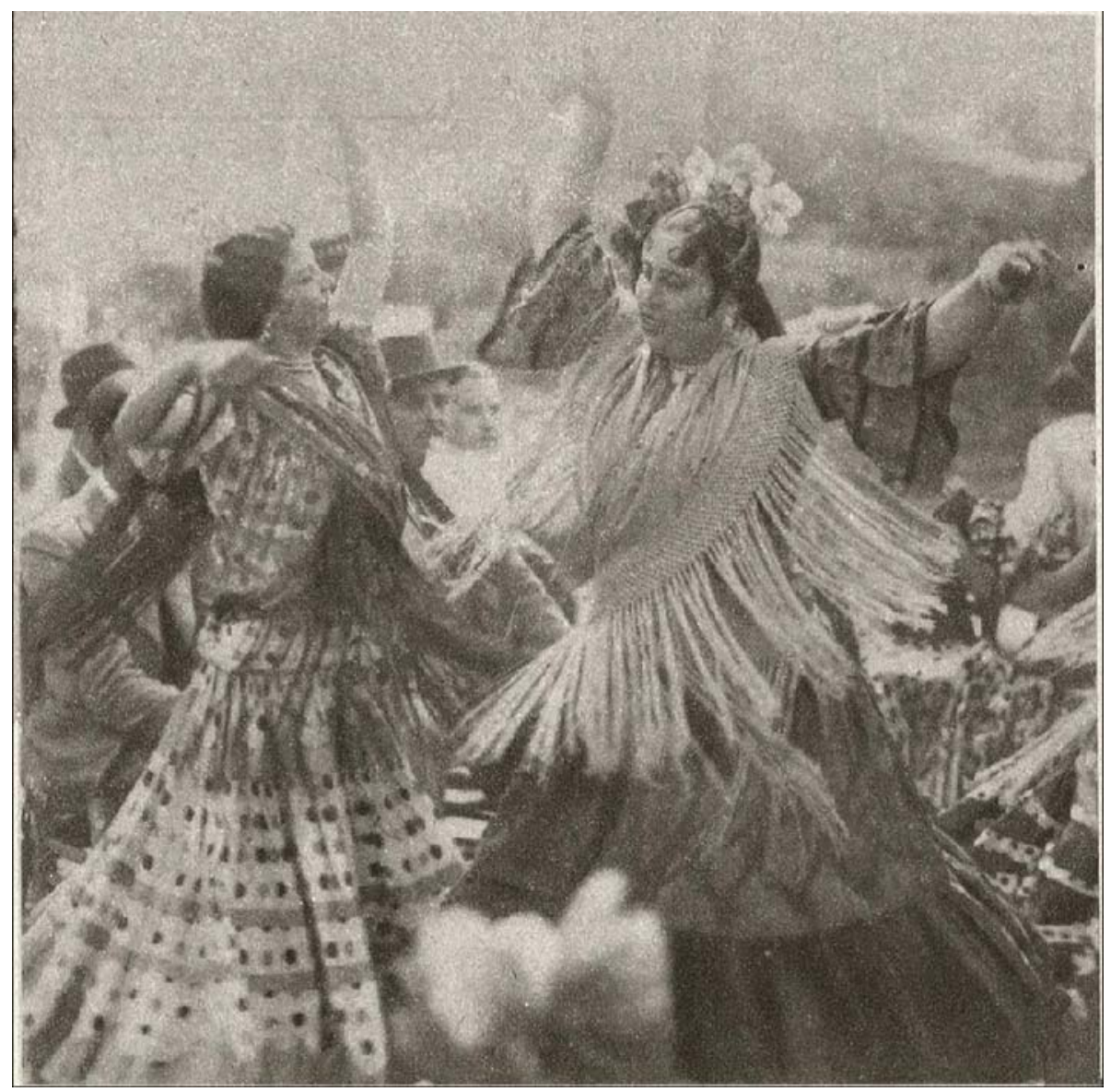

Figure 8. The sale of the gypsy dancer through her dancing for the 'English' ('Maria de la O', 1936). Source: Filmoteca Nacional de Catalunya.

admiring bullfighter and her fiancé, the humble silversmith 'Juan Miguel'. The money, and the sale of folklore (and of 'María de la O' herself) are the crux of the plot of this españolada that focuses on the encounter between the gaze of tourists in Granada, admirers of the fantasies of Washington Irving, and the cinematographic promotion of the Andalusian gypsy.

Thus, the sale of this gypsy dancer begins with the scene in Granada's Sacromonte, with a fabulous view of the Alhambra and the possibility of witnessing an 'authentic' gypsy zambra. The paid artists cheer some 'English' tourists (with round glasses and typical suits), who cannot understand them: 'Let all the English or the sons of Philadelphia come, ole, ole'; 'Let all the painters and foreigners from Philadelphia come'. Tourist and spectator are complicit as they observe the commercialisation of nationalised Spanish folklore, through an orgy of dance and flurry skirts (see Figure 8).

In this sense, Palomeque Recio (2012, p. 168) believes that 'the relationship of María de la $\mathrm{O}$ and her stepmother with the male universe testify [...] to the existence of a vision [...] allied to both men and economic power' that turns the gypsy dancer into merchandise for sale. The work of this researcher can corroborate that the film extends its observation to 
the economic side of tourism, since 'as a child, the camera focuses on her closely, in headshots and medium shots (only her stepmother sees her); [...] as an adult, the shot becomes longer, allowing the public into it. This widening of the shot, which includes her body and her skill as a dancer, suggest the presence of a greater number of men who strive to possess her-at the same time as she becomes a commercial product', this being her only means of achieving social mobility and escaping her fate as a 'gypsy on the road'.

The use of tourism and tourists by the Gypsy community is striking, as it not only speaks of the picaresque nature attributed to this ethnic group, but also of the scarce (and unreal) possibilities of integration between social classes, despite the cinema of the Second Republic being committed to the assimilation of the Gypsy community. Utrera sees the character of 'Argote' (official guide of the SpanishTourism Board) as acting as a mediator between both worlds. The character appreciates the tension caused by foreign tourists in a gypsy camp '[...] populated by dancers, bullfighters and hustlers who maintain a permanent conflict between belonging to their world (to their identifying traits and its resulting poverty) and their contact with the non-gypsy world, (which is hostile, but which offers the possibility of escape from misery)' (Sánchez Oliveira, 2003, p. 110).

This is only achieved through marriage, the sex trade without barriers or selling their dances for tourism. When the tourist 'Mister Moore' buys Andalusian folklore with what is effectively the commercialisation of 'María de la $\mathrm{O}$ ', he breaks with the subtle conventions of that flamenco world that allows the sale but not the possession of the 'gypsy dancers', thus stigmatising the protagonist (see Figure 9). She is freed from the offence by returning to her family and marrying innocently, showing that folklore can cohabit with tourism without prostitution. By accepting herself as the daughter of a non-gypsy, the daughter of a foreigner, but the wife of a gypsy, 'María de la $\mathrm{O}$ ' establishes a new fusion between national folklore and the gypsy group for tourism.

\subsection{Years of Lead (1940-1959): Carmen 'Catholic and decent'. 'Pan, Amor y Andalucía' ('Bread, Love and Andalusia', 1958)}

It is during the 'Years of Lead' period that the greatest dissociation of the two concepts of our study occurs ('Spanish Gypsies' and 'Flamenco World', associated with 'Andalusian Women'). Thus, although a noticeable decrease is observed in terms of the diffusion of the stereotype of gypsies (-64\%), the most significant trend is the increase in the variable 'Flamenco World' (138.77\% compared to the previous period; see Figure 2), which is not associated with the authentic representation of the gypsy community, but with the rise of female folk artists who do not belong to this ethnic group ('white gypsies', according to Woods Peiró, 2012)

Colmeiro states that 'the myth of Carmen has functioned in modern Spanish culture as a privileged symbolic vehicle to negotiate and suture the tensions of a national identity that has been frequently imposed by hegemonic forces' $(2009$, p. 1). Thus, 'the españolada films under Franco presented an idealised, unified and unproblematic view of national identity based on stereotypes of traditional folkloric life (mostly Andalusian in representation of the nation). This view was profoundly conservative, patriarchal 


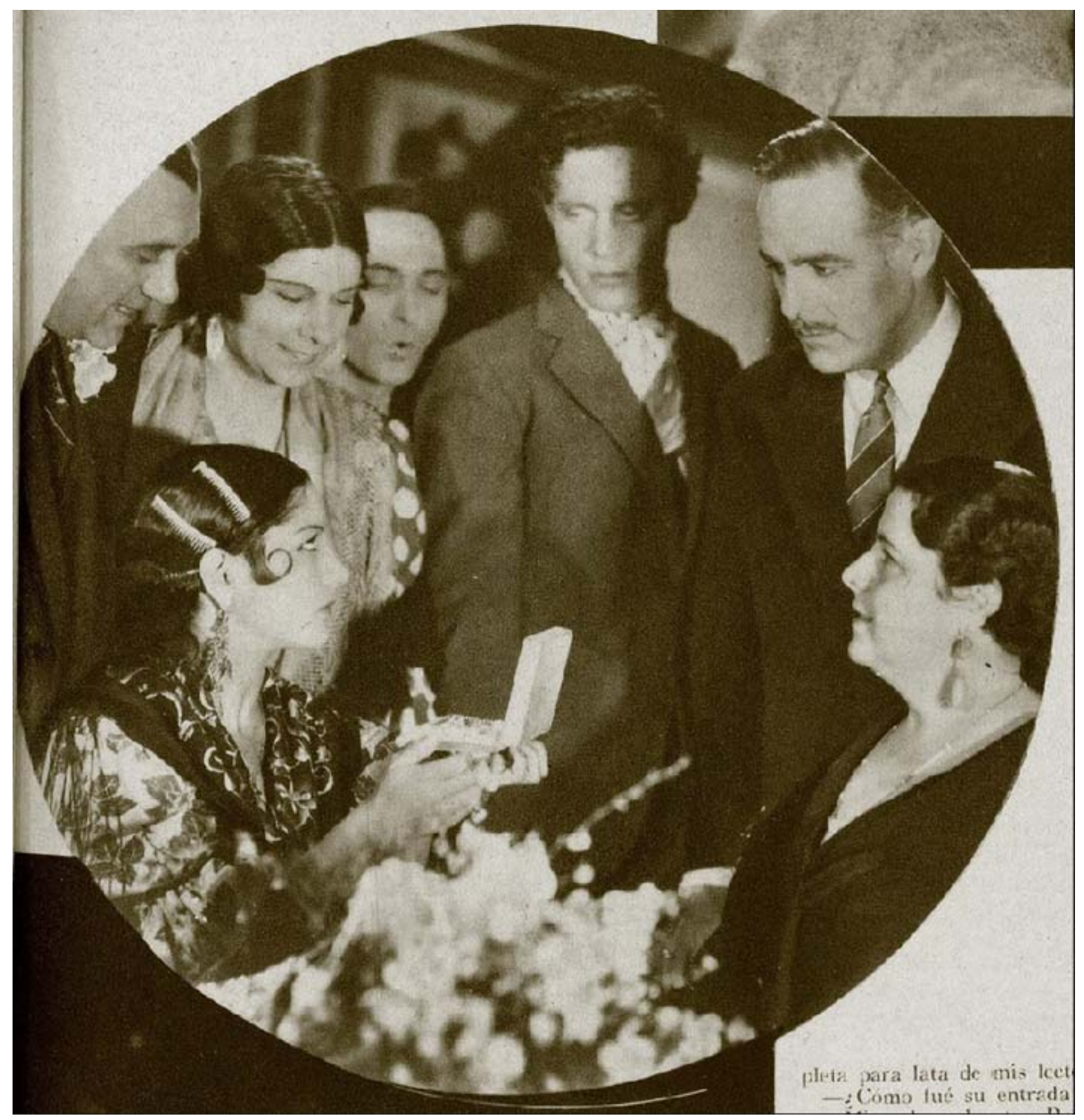

Figure 9. The sale of the gypsy dancer through the sex trade ('Maria de la O', 1936). Source: Filmoteca Nacional de Catalunya.

and hierarchical undertones, in line with the anti-modern bias of the Franco regime's nationalist ideology of the 1940s and 1950s' (2009, p. 6)

Palomeque Recio (2012, p. 153). refers to '[...] the line of argument drawn by Jo Labanyi as typical of the españolada films of the early years of the Franco regime', in which 'the lower-class heroine (usually a gypsy), who represents the people, [is] given to the upper-class man (usually a landowner) only after using her power of seduction to ensure his surrender to her cultural values' (Labanyi, 2002, p. 209). Palomeque insists that the last stage of the folkloric españolada genre '[...] has been widely studied because of the regime's well-known use of the female image of the folkloric singer as a banner for the main moral values attributed to women: honesty, chastity, -potentialmotherhood and submission, in a context of absolute media control as a way to achieve the desired national, territorial and ideological unity'.

This submissive image of women, far from the rougher side of the 'Flamenco World' is now applied to the great folkloric stars of the period, and by doing so helps to shape a 
new variant of the myth: the sparkling and entertaining 'Carmen' of early Francoism. Thus, the protagonist of 'Pan, Amor y Andalucía' ('Bread, Love and Andalusia', a film that brings together 9 references to the 'Flamenco World') is also called 'Carmen' ('Carmen, fateful name. Love and death. Blood and sand. Pride and passion ... '); she works in a 'night club' in Seville before an audience mainly made up of tourists ... but her mercenarism is limited to her singing and dancing, since she lives with her mother and does not allow the wiles of a foreigner (Vittorio De Sica) to cast a shadow of doubt on her honour (see Figure 10).

As the pattern defined by Labanyi requires, this 'Carmen' also manages to conquer an Andalusian landowner (Vicente Parra), using tourism as a means to alleviate the tension between classes and, more specifically, with Vittorio De Sica. This tourist is, principally, the excuse that provokes the misunderstanding and who, later, re-emerges as a conciliatory figure that brings about a happy ending (see Figure 11).

'Pan, Amor y Andalucía' is a celebration of hedonism, focussing on the desires of European tourists visiting romantic Spain: '[...] I am about to take you to Spain, to Andalusia, the land of sun and love!' Once there, and completely captivated by the city (and the opportunities for female conquests that it allegedly offers), the Italian tourist will scold his sidekick ('Hey, Peppì, you only live once! We're in Seville!'; 'Sleep! Sleep! Am I supposed to come to Seville to sleep?'), and when he sees 'Carmen' dancing in the 'Venta Española', he will not be able to stop his desires from taking shape ('Have you seen what fire, what passion? Peppì, I am afraid of falling in love').

However, the españoladas of early Francoism were responsible for highlighting that the supposed modernity and openness of Andalusian women to tourists was nothing

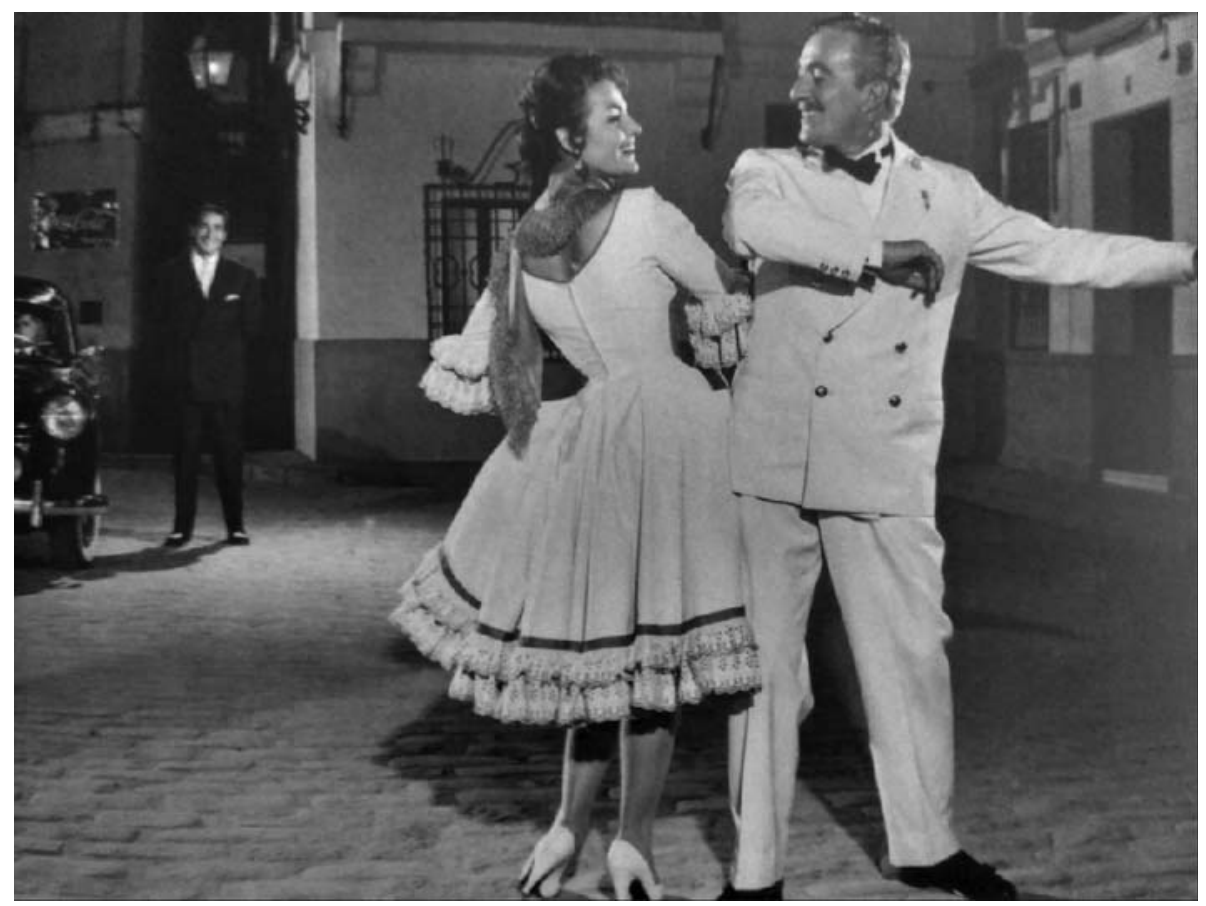

Figure 10. 'Carmen' ('Pan, Amor y Andalucía', 1958) flirts with tourism. Source: the author's collection. 


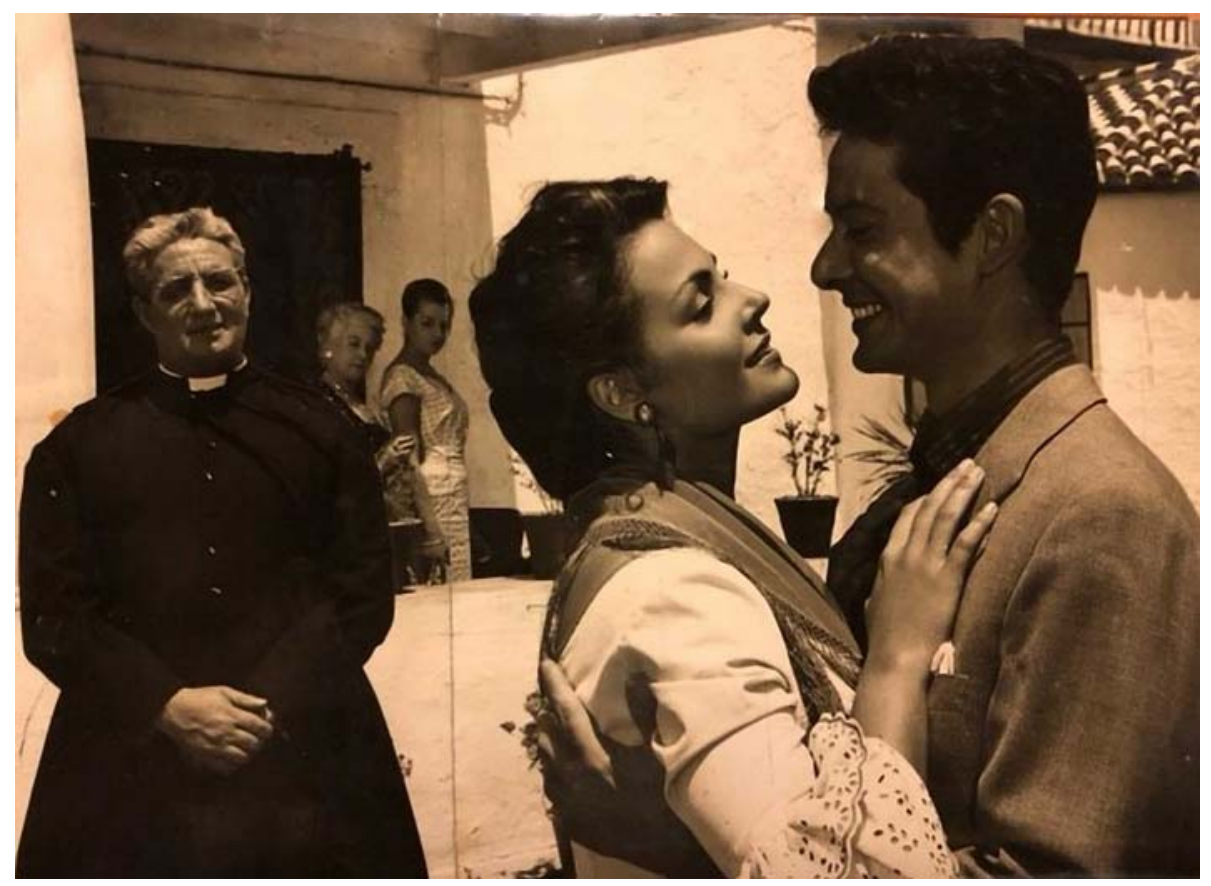

Figure 11. A happy ending means marrying a traditional Andalusian landowner ('Pan, Amor y Andalucía', 1958). Source: the author's collection.

more than a pose. This Andalusian woman might work in tourism in the capital of Andalusia, but she is 'Catholic and decent', as stated in the assertive song by Quintero, León and Quiroga, written for the tonadillera Juanita Reina (Pérez Rodríguez, 2008) and which, nevertheless, would become an anthem of Andalusian charm that Carmen Sevilla, the protagonist of 'Pan ...', exploited for decades on the stages of Spain.

Thus, the film warns that, despite the (bad) reputation of Andalusian women, they shouldn't be joked about: 'Andalusian women ... you mustn't fool with them!'. This 'Carmen' is, as De Sica himself notices, 'a symbol of Andalusia in bloom' (Figure 12), a 'white gypsy' who makes up for her shortcomings as a singer (after being advised by the incidental character played by the mythical Pastora Imperio) by performing spectacularly beautiful dances, wrapped in luxurious long-trained dresses, smiling for the tourists.

Gallardo Saborido thus takes up Jo Labanyi's theory of 'parodic mimicry', 'thanks to which female folk artists were able confront the viscous stereotype in which they had been typecast'. Because 'through excessive melodramatisation [...] they would manage to parodically subvert the Andalusian stereotype in which they were trapped. On the one hand, the audience was aware that they were witnessing a simulation [...], since they knew that many of the stars who embodied the Gypsy characters did not belong to that community. On the other hand, the emphasis placed on flamboyance, both in the acting style of the protagonists and in the professional roles of the singers and/or dancers often played by them in the films, emphasize the parodic significance [...]' (2010, p. 31). Thus, we are witnessing the beginning of the spectacularisation of Andalusia and its 'white gypsies' on sale for tourists. 


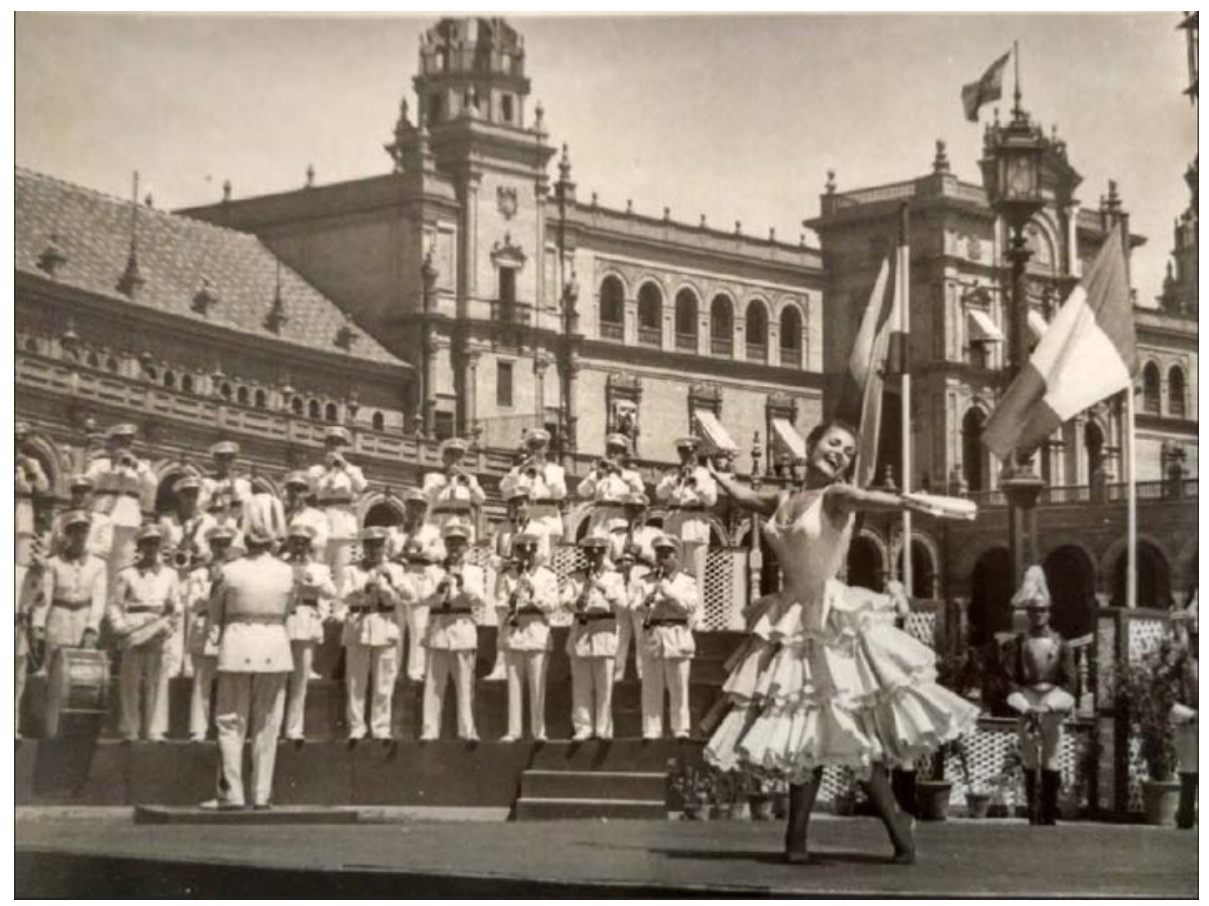

Figure 12. 'Carmen' ('Pan, Amor y Andalucía', 1958) participates in the international band competition. as 'a symbol of Andalusia in bloom', a flamboyant flamenco doll. Source: the author's collection.

\section{Discussion and conclusions: 'Carmen' in Granada, Seville ... and the Costa del Sol. Rebirth of a global myth}

Our work pivots on the two pillars regarding Andalusian women defined by Jo Labanyi (2004) in the españoladas folklóricas of early Francoism. These are that Andalusian women are (in reality or supposedly) 'Spanish Gypsies' and that they belong to the world of flamenco show business. Our objective is to discern the impact of these two concepts during earlier and later periods and to discover how Bizet's mythical 'Carmen' was transformed into a consumer product when it came into contact with an increasingly standardised, global mass tourism.

This study suggests that, during the first decades of the twentieth century, when the figure of the tourist is perceived as anecdotal, depictions of Andalusian women appear balanced in terms of their relationship with the 'Flamenco World' and the community of 'Spanish Gypsies'. This balance will be upset when during early Francoism the depiction of the 'white gypsies' is consolidated, after first being put forward during the Second Republic, and alongside it the relentless association of Spanish folklore with the 'Flamenco World'. This is the moment when tourism in Spain takes 'a great leap forward' (Pack, 2009), and it seems that the portrayal of the myth becomes problematic for the tourist industry because of the racial issues associated with it. Therefore, the idea of a self-interested racial construct involving the ethnic group during the Franco period is strengthened (Woods Peiró, 2012; Labanyi, 2004; Charnon-Deustch, 2002), not only with the objective of presenting an unequivocal national identity, but also to display it to tourists and market its most compelling character. 
This play of identities and cultural artefacts, which is said to be exhibitionism on the part of the Andalusians (Ortega y Gasset, 1927), but which the Spanish accept with tacit agreement (aware of its inauthenticity), is distributed transnationally and reaches its peak at this point. The icon of the Andalusian woman was getting ready to become the ideal holiday souvenir of the subsequent period (1960-1975). Along these lines, if we follow the theories of Palomeque Recio, in which the words look, gaze and screen determine the relevance of the portrayal of the gypsy dancer in the cinema, we will conclude that it is during early Francoism when the clear, recognisable image of this cinematographic 'Carmen' becomes established in the public's imagination. This is brought about through the association of folkloric stars with flamenco shows, and the subsequent creation of a new, more amenable and exportable depiction of Andalusian women for the tourist industry.

In this way, the association with the aggressive literary and operatic 'Carmen' fades, and more emphasis is placed on a less racial and authentic, but more flamboyant version of the myth. Attitudes and cultural contexts evolve and banish both the femme fatale dress of 'Sibilla' and the ethnic authenticity of 'María de la O', in favour of a 'Carmen' who is flirtatious and easily consumed on holiday; a 'Carmen' that even becomes anonymous so that it can be bought in shops and tablaos during the 1960s and 1970s.

This turning point can be seen both in cinema and in tourism. In the first case, it should be noted that the first two examples are works by brilliant international directors (Marcel L'Herbier and Francisco Elías), and they retain their authorial signature when it comes to transferring the myth of Andalusian women to the big screen. These visions are intended for French and Spanish audiences who are interested in the new forms of melodrama and the artistic stylisation of Spain and who are eager to contemplate real tradition revolving around the figure of the Spanish gypsy dancer, respectively. In the last two stages, however, the portrayal of the tourist 'Carmen' is left in the hands of mediocre directors (as is the case of Javier Setó) or of filmmakers specialised in the new tourist españolada of the developmentalist period, in which signs of authorship are diluted and the Andalusian woman gets on the stage and practically vanishes. These films are designed for a transnational less-demanding audience or even exclusively for the Spanish who are keen on participating in the phenomenon of tourism.

As for the second case, although the tourist who appears in 'El Dorado' and 'María de la $\mathrm{O}$ ' adheres to the model of the romantic traveller who follows in the footsteps of Washington Irving, it makes clear the inequality of relations between the gypsy folklorist and the tourist. In the last two stages the trend is reversed, highlighting the use that the tourist industry makes of these archetypes both for visitors to Seville and the Costa del Sol, as tourism begins to dominate the storylines.

Tourism will also act as a catalyst in the destinies of these film 'Carmens' and their cultural development, from the French espagnolade of the early twentieth century to the tourist españolada of the 1960s and 1970s. So, our first 'Carmen' (the femme fatale 'Sibilla') is condemned by what Naomi Segal has called 'a literary and cultural version of femicide' (2017) after her only contact with civilisation and even 'María de la O' must suffer great hardships to achieve her happiness after the intervention of 'Mister Moore'. In contrast, the 'Carmen' of 'Pan, Amor y Andalucía' resists adversity and the doubting of her honour as a sparkling figure, amenable to tourists. The later versions of the 
myth, which are totally frivolous and tedious, are content with letting the visitor take the lead and the floor, while they dance on the stage for him.

So, if we take that 'Carmen' from 1958 as an example, we will appreciate that she is not very convincing when singing the 'Coplas, coplas from my Spain' that 'nobody [...] knew

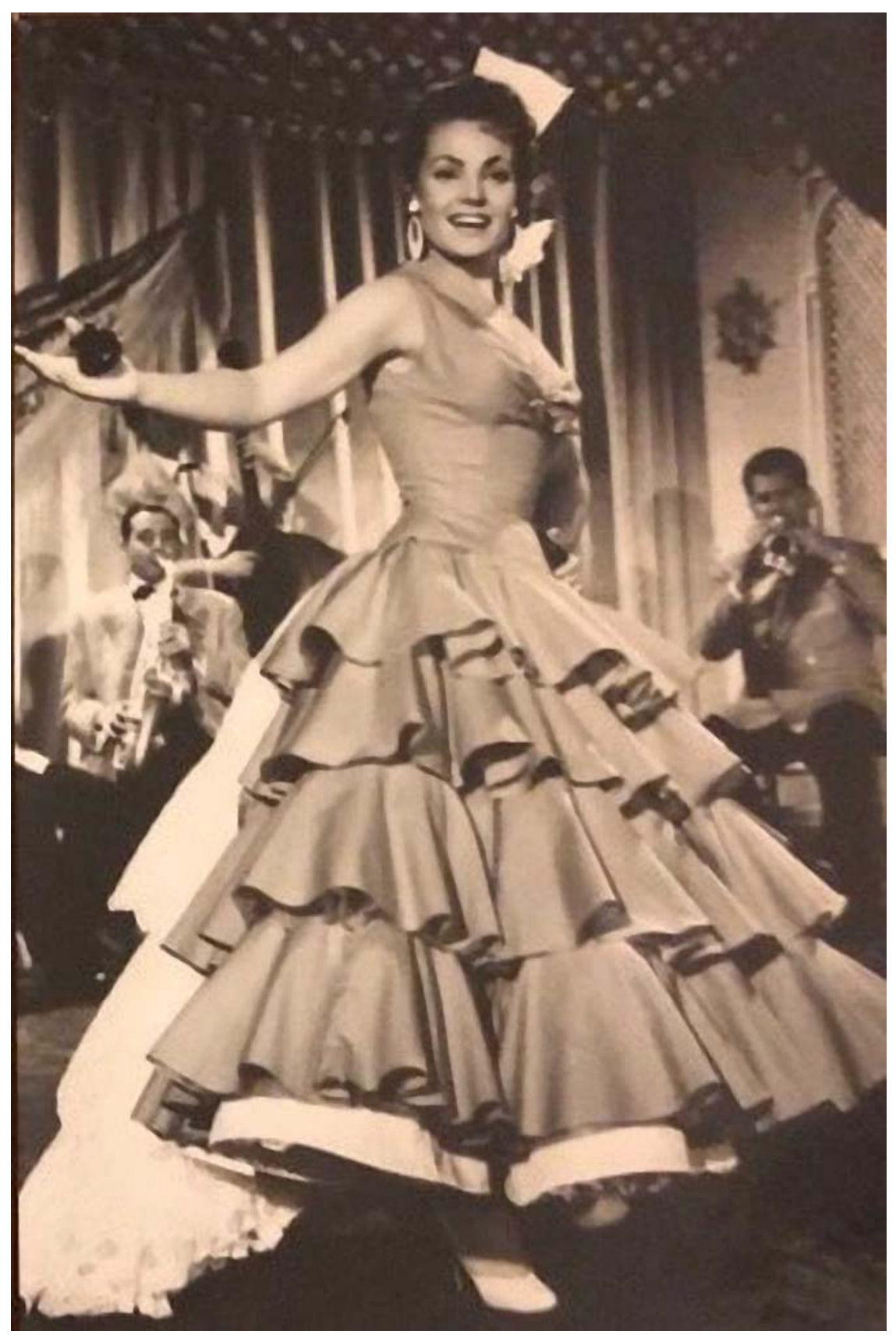

Figure 13. Carmen Sevilla diplays her beaming smile ('Pan, amor y Andalucía', 1958). Source: the author's collection. 


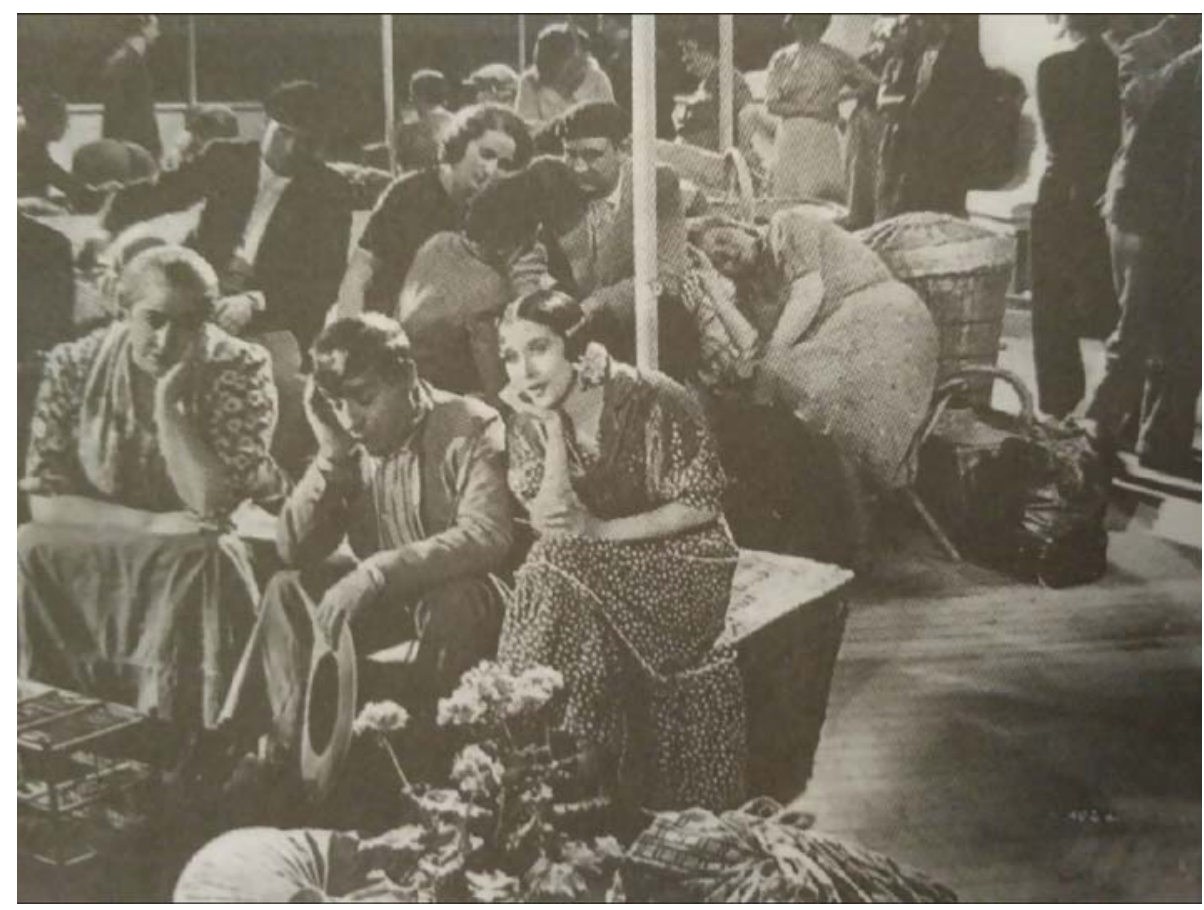

Figure 14. Estrellita Castro weeps in 'Suspiros de España' (1938). Source: the author's collection.

how to copy', declaring that 'if I hear them in a foreign land / I want to cry' with a broad, flirtatious smile (Figure 13). This famous pasodoble exemplifies the path travelled by Spanish folklore and folkloric singers themselves, from 'Suspiros de España' and the tears 'in a foreign land' (played by Estrellita Castro in the film of the same name in 1938; Figure 14) to this clichéd display in a tourist tablao in Seville. In this respect, Aoyama has highlighted the decay of flamenco music for tourists (2007, p. 111), which is in line with the degradation of the 'Carmen' myth shown in films with tourists during the period 1950-60. Because if anything began to be copied during the 1950s it was precisely the copla for the tablaos and the tonadilleras as souvenirs.

Thus, if 'Peppino', the conventional tourist of 'Pan ...' ', does nothing but buy ridiculous souvenirs (either a Cordoban hat, or a bullfighter's or a picador's hat), Vittorio De Sica will also try to take his own particular souvenir back to Italy in the form of the little flamenco doll Carmen Sevilla. However, the attitude of this 'Catholic and decent Carmen' will make him desist and, after comical, repeated attempts to enter a convent, he will have to be content with blessing the happy Andalusian couple and running away from his romantic dream in the Barrio de Santa Cruz.

From that moment on, the anonymity of this 'Carmen' from the tablao will lead to the standardised marketing of the well-known flamenco doll, crossing even the thresholds of Spanish homes. Thus the flamenco doll surpassed the figure of 'Carmen' by becoming a symbol of tourism in Spain during the 1960s and 1970s. Late Francoism saw the enthusiastic association of Spaniards with the increasingly popular tourism authorities (the Spanish Ministry of Information and Tourism) as a way of giving shape to a new developmentalist Spanish identity. To feel themselves part of the phenomenon of tourism, the 
Spanish conformed to a normative cinema genre (tourist españolada), and recreated their most marketable myths and folklore, aware, once again, of the evident degradation of these cultural products.

In this vein, the sale of gypsy costumes and the emulation of flamenco characters by foreign characters would become a constant feature of the films, transforming the Andalusian characters into mere extras from the tertiary sector. Thus, the French tourist from 'Los duendes de Andalucía' (1966) dresses up as a sweet flamenco 'Carmen' to attend the Feria de Abril, like another little doll symbolising Spain (see Figure 15). Until then, if a foreign tourist had dared to dress in flamenco costume (María Isbert in 'Currito de la Cruz', 1949, or Mary Santpere herself in 'Veraneo en España', 1956), she would have been the laughing stock of the local characters.

So folklore became just one more mass-produced product to offer them, made up of indistinguishable and interchangeable flamenco figures: little flamenco dolls offered to tourists with as much determination as indifference, and in various languages (as in the tablao depicted in the film 'Me has hecho perder el juicio', 1973). The idea of Andalusia/Spain was then developed through a new fantasy in which the banality of costume survived as a show in itself (popularly known as 'Typical Spanish') and in which the figure of 'Carmen' evolved towards its conversion into a childish consumer product, which continues to be successful among tourists who visit Spain. Nevertheless, a more profound connection between the primitive images of 'Carmen' put forward in this paper and the image current tourists have can be discerned, since the 'Flamenco World' enjoys today '[...] the diffusion of a cultural product [that] interacts with contemporary globalization [...]' (Aoyama, 2007, p. 104) and the new forms of travel and mobility.

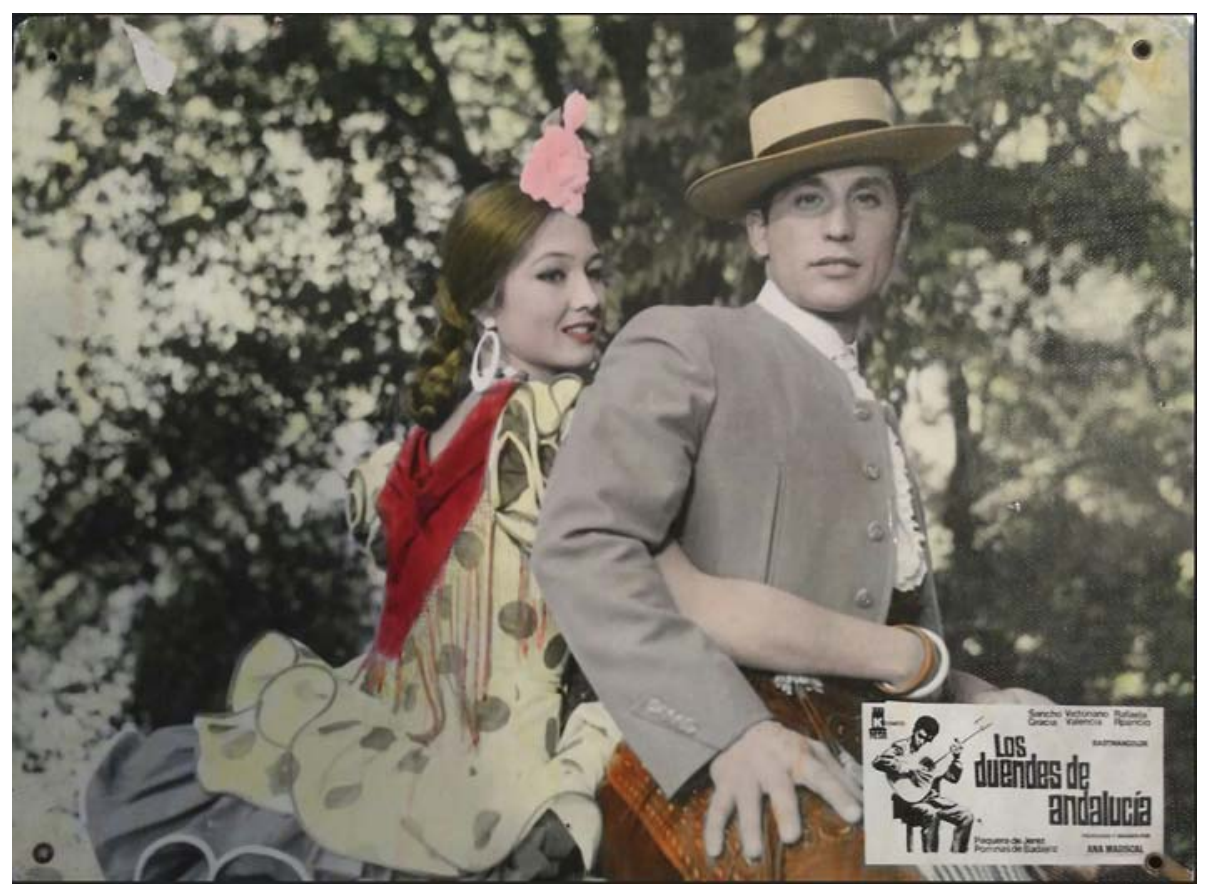

Figure 15. Tourists in the films buy flamenco dresses as souvenirs to recreate the experience of 'Carmen'. Source: the author's collection. 
Recent studies show how foreign female flamenco aficionados are '[...] expressing otherwise suppressed desire, anger, and sensuality [...]' (Aoyama, 2007, p. 108), as well as embracing '[...] the Gypsies' struggle within Andalusia' (Matteucci, 2014, pp. 33-34). Thus, flamenco helps tourists '[...] to remedy a lack of self-esteem', which is related with '[...] the stereotyped representation of the sensual flamenco dancer [...]', but also with her prominent cultural ambiguity. Even when the corny flamenco doll still awaits tourists in the shop windows, Sevillian tourism authorities have created the '[...] image of the city with the usual flamenco attributes: passion, eroticism, idiosyncratic' (Thimm, 2014, pp. 584-585). A fascinating and contradictory cultural phenomenon worthy of continued study and verification.

\section{Acknowledgement}

This work was supported by the Spanish Ministry of Science and Innovation/State Research Agency/ ERDF, UE under Grant PGC2018-095992-B-I00, Project 'Territorial intelligence vs. tourism growth. Tourist destination management and expansion of the real estate sector', and also by the Spanish Ministry of Science and Innovation/State Research Agency/ERDF, UE under Grant RTI2018-094100-B-I00, Project 'Spanish towns in audiovisual fiction film. Documentary record and audiovisual analysis of the territory (FACES-50)'. As far as I know, there are no competing interests to disclose.

\section{Disclosure statement}

No potential conflict of interest was reported by the author(s).

\section{Funding}

This work was supported by the Spanish Ministry of Science and Innovation/State Research Agency/ ERDF, UE [Grant Number PGC2018-095992-B-I00 and Grant Number RTI2018-094100-B-I00].

\section{Notes on contributor}

Maria C. Puche-Ruiz is specialised in conservation of Cultural Heritage and management of local development, and was a tourist planning consultant at the Spanish Tourism Board (Spanish Ministry of Tourism, Tourspain, 2010-2012). She received her PhD in Geography from the University of Seville, where she was a postgraduate researcher from 2014 to 2018. She also was a visiting researcher at the Universite Paris 1 - Panthéon Sorbonne (2015), the University of Leeds (2016), and the University of Birmingham (2017), supported by the Spanish Ministry of Education and Culture, and has participated in several prestigious national and international conferences.

As a postdoctoral researcher Maria C. Puche is member of the R\&D team 'Territorial and Tourism Studies' (University of Seville), and the international research network 'CITur' ('Cinema, Collective Imaginary and Tourism', led by the University of Valencia). Since 2018, she has been a team member of the Project 'Spanish Towns in Audiovisual Fiction. Documental Record and Territorial Analysis', conducted by the University Carlos III of Madrid. She has focused her academic research on the relationship between national and territorial identity and cinema, with special stress on the analysis of films that show the tourist experience and tourism policies in Andalusia. 


\section{ORCID}

Maria C. Puche-Ruiz (10) http://orcid.org/0000-0003-3689-0183

\section{References}

Aoyama, Y. (2007). The role of consumption and globalization in a cultural industry: The case of flamenco. Geoforum; Journal of Physical, Human, and Regional Geosciences, 38, 103-113. doi:10. 1016/j.geoforum.2006.07.004.

Barroso, MÁ, \& Gil-Delgado, F. (2002). Cine español en cien películas. Madrid: Ediciones Jaguar.

Benet, V. J., \& Biosca, V. (2013). La españolada en el cine. In J. Moreno Luzón \& X. M. Núñez Seixas (Eds.), Ser españoles: imaginarios nacionalistas en el siglo XX (pp. 560-591). Barcelona: RBA.

Cerdán, J. (1997). Silencios y ruidos en torno a la llegada del sonoro a España. Archivos de la Filmoteca, 27, 74-88. Retrieved from http://www.archivosdelafilmoteca.com/index.php/ archivos/article/view/330

Charnon-Deustch, L. (2002). Travels of the Imaginary Spanish gyspy. In J. Labanyi (Ed.), Constructing identity in contemporary Spain. theoretical debates and cultural practice (pp. 22-40). New York: Oxford University Press.

Cipriani, R., \& Del Re, E. C. (2012). Imagination and society: The role of visual sociology. Cognitive Processing, 13(2), S455-S463.

Cisneros-Kostic, R. E. (2010). Flamenco and Its Gitanos. An Investigation of the Paradox of Andalusia: History, Politics and Dance Art. Retrieved from https://digitalrepository.unm.edu/thea_etds/3

Claver Esteban, J. M. (2012). Luces y rejas. Estereotipos andaluces en el cine costumbrista español (1896-1939). Sevilla: Centro de Estudios Andaluces.

Colmeiro, J. F. (2003). El Oriente comienza en los Pirineos (La construcción orientalista de Carmen). Revista de Occidente, $n^{\circ} 264,57-83$.

Colmeiro, J. F. (2009). Nationalising Carmen: Spanish cinema and the spectre of Francoism. Journal of Iberian and Latin American Research, 15(1), 1-26. doi:10.1080/13260219.2009.9649900

Cruces-Roldán, C. (2017). Bailarinas fascinantes: género y estereotipos de "lo español" en el cine primitivo (1894-1910). Bulletin of Spanish Visual Studies, 1(2), 161-192. doi:10.1080/24741604.2017. 1342438

Davies, A., \& Powrie, P. (2006). Carmen on screen. An annotated filmography and bibliography. Woodbridge: Tamesis.

Gallardo Saborido, E. J. (2010). Gitana tenías que ser. Las Andalucías imaginadas por las coproducciones filmicas España-Latinoamérica. Sevilla: Centro de Estudios Andaluces.

Gravari-Barbas, M. (2019). What makes Paris being Paris? Stereotypes, simulacra and tourism imaginaries. Journal of Tourism and Cultural Change, 17(1), 27-41. doi:10.1080/14766825.2019.1560765

Griñán Doblas, F. (2016). Stereotypes and archetypes in early Spanish cinema. New Review of Film and Television Studies, 14(4), 487-503. doi:10.1080/17400309.2016.1203213

Guarinos, V. (2010). Carmen global: el mito en las artes y los medios audiovisuales. Sevilla: Secretariado de Publicaciones de la Universidad de Sevilla.

Gubern, R. (1977). El cine sonoro de la II República. Madrid: Lumen.

Hamling, A. (2010). Carmen, flamenco and the Spanish Gypsies: An introduction. International Journal of Interdisciplinary Social Sciences, 5(6), 193-198. doi:10.18848/1833-1882/CGP/v05i06/ 51757

Hernández-Girbal, F. (5 de abril de 1936). Viendo rodar María de la O. Cinegramas, Año III(Núm. 82), $1-2$.

Hernández, J. (2008). La imagen de Andalucía en el turismo. Sevilla: Centro de Estudios Andaluces. Ionita, C. E. (2013). 'The Educated Espectator: Cinema and Pedagogy in France, 1909-1930'. Doctoral Thesis, School of Arts and Sciences, Columbia University. doi:10.7916/D8HQ3ZXR.

Labanyi, J. (2002). Musical battles: Populism and hegemony in the early francoist folkloric film musical. In J. Labanyi (Ed.), Constructing identity in contemporary Spain. Theoretical debates and cultural practice (pp. 206-221). New York: Oxford University Press. 
Labanyi, J. (2004). Lo andaluz en el cine del franquismo: los estereotipos como estrategia para manejar la contradicción. Sevilla: Centro de Estudios Andaluces. Retrieved from https://www. centrodeestudiosandaluces.es/publicaciones/lo-andaluz-en-el-cine-del-franquismo-los-estereotipo s-como-estrategia-para-manejar-la-contradiccion

Lénárt, A. (2012). En busca del concepto de cine nacional español. Acta Hispanica, Tomus XVII, 103114.

Lu, Z. (2009). Carmen: The oriental woman in the west and the occidental woman in the east. Foreign Literature Studies, 31(4), 122-129.

Luque Teruel, A. (2004). Sobre la afirmación del Cinematógrafo como un medio expresivo de la Vanguardia Parisina. Ars Longa, 13, 111-120. Retrieved from https://ojs.uv.es/index.php/ arslonga/article/view/11808

Marinero Labrador, C. (2012). El baile fragmentado de Carmen Amaya en María de la O. La Madrugá, Revista de Investigación Sobre Flamenco, $n^{\circ} 7,157-181$.

Matteucci, X. (2014). 'Forms of body usage in tourists' experiences of flamenco'. Annals of Tourism Research, 46, 29-43. doi:10.1016/j.annals.2014.02.005.

Medrano García, S. (1990). 'Carmen', de la literatura a la imagen. Barcelona: Universitat de Barcelona.

Mestre, R., Del Rey, A., \& Stanishevski, K. (2008). The image of Spain as tourist Destination built through fictional cinema. Journal of Travel \& Tourism Marketing, 24(2-3), 185-194. doi:10.1080/ 10548400802092718

Ortega y Gasset, J. (1927). Teoría de Andalucía. In Ortega y Gasset (Ed.), Obras completas (2004) (Vol. VI, pp. 175-183). Madrid: Taurus / Fundación Ortega y Gasset.

Pack, S. D. (2009). La invasión pacífica. Los turistas y la España de Franco. Madrid: Turner.

Palomeque Recio, A. (2012). Cómo mirar: Vaivenes de la agencia femenina en el cine de la "españolada" durante la II República y el franquismo. Sesión no numerada: Revista de letras y ficción audiovisual, 2, 152-173.

Payelle, R. (1921). El Dorado. Mélodrame cinématographique par Marcel L'Herbier. Paris: Éditions de la Lampe Merveilleuse.

Pérez Rodríguez, D. (2008). Evolución del retrato literario del mito de Carmen en tres textos musicales españoles del siglo XX. Ogigia, Revista electrónica de estudios hispánicos, 4, 59-67.

Perriam, C., \& Davies, A. (2005). Carmen. From silent film to MTV. Amsterdam: Brill/Rodopi.

Powrie, P., Babington, B., Davies, A., \& Perriam, C. (2007). Carmen on film. A cultural history. Bloomington: Indiana University Press.

Prieto Arranz, J. I. (2006). 'Rural, white and straight. The ETC's vision of england'. Journal of Tourism and Cultural Change, 4(1), 19-52. doi:10.1080/14766820608668497

Pujante Segura, C. (2010). El mito de Carmen a finales del siglo XX: desmitificación o remitificación. In M. Cots Vicente, \& A. Monegal (Coord.), Actas del XVII Simposio de la Sociedad Española de Literatura General y Comparada, vol. 1 (pp. 379-390). Alicante: Biblioteca Virtual Miguel de Cervantes.

Rose, G. (2012). Visual methodologies: An introduction to researching with visual materials (3rd ed). London, UK: Sage.

Sánchez Oliveira, E. (2003). Aproximación histórica al cineasta Francisco Elías Riquelme (1890-1977). Sevilla: Publicaciones de la Universidad de Sevilla.

Segal, N. (2017). The femme fatale: A literary and cultural version of the femicide. Qualitative Sociology Review, 13(3), 102-116. Retrieved from Retrieved from http://www.qualitative sociologyreview.org/ENG/Volume42/QSR_13_3_Segal.pdf

Sentaurens, J. (2002). Carmen: de la novela de 1845 a la zarzuela de 1887. Cómo nació "la España de Mérimée". Bulletin Hispanique, 104(2), 851-872. Retrieved from https://www.persee.fr/doc/hispa_ 0007-4640_2002_num_104_2_5136

Serrano, C. (1999). El nacimiento de Carmen. Madrid: Taurus.

Shandley, R., Jamal, T., \& Tanase, A. (2006). Location shooting and the filmic destination: Transylvanian myths and the post-colonial tourism enterprise. Journal of Tourism and Cultural Change, 4(3), 137-158. doi:10.2167/jtcc056.0

Strauss, A., \& Corbin, J. (1999). Basics of qualitative research: Techniques and procedures for developing grounded theory (2nd ed). London: Sage. 
Thimm, T. (2014). The flamenco factor in destination marketing: Interdependencies of creative industries and tourism - the case of Seville. Journal of Travel and Tourism Marketing, 31(5), 576-588. doi:10.1080/10548408.2014.883952

Utrera, R. (1997). Imágenes cinematográficas de Sevilla. Sevilla: Padilla Libros.

Utrera, R. (1998). María de la O. In J. Pérez Perucha (Ed.), Antología crítica del cine español. 1906-1995 (pp. 107-109). Madrid: Cátedra/Filmoteca Española.

Vera, M. T., \& Meléndez, N. (2008). El mito de Carmen: Exotismo, Romanticismo e Identidad. Ámbitos, 17, 343-354. doi:10.12795/Ambitos.2008.i17.21

Woods Peiró, E. (2012). White gypsies. Race and stardom in Spanish musicals. Minneapolis: University of Minnesota Press. 